\title{
The Implementation of 7 Smart Reading Strategies in Improving Students' Reading Comrehension at the First Grade Students of SMA 9 Makassar
}

\author{
M. DAHLAN BAHANG *, NUR AENI KASIM \\ English Department of STKIP YPUP Makassar, South Sulawesi, Indonesia
}

How to cite this paper: BAHANG, M. D., KASIM, N. A. (2019). The Implementation of 7 Smart Reading Strategies in Improving Students' Reading Comrehension at the First Grade Students of SMA 9 Makassar. The Educational Review, USA, 3(12), 215-219.

http://dx.doi.org/10.26855/er.2019.12.003

*Corresponding author: M. DAHLAN BAHANG, English Department of STKIP YPUP Makassar, South Sulawesi, Indonesia.

E-mail: mdahlan.hbahang@gmail.com

\begin{abstract}
The objective of this research is to find out whether or not the Implementation of 7 Smart Strategy Reading can improve the reading comprehension of the first grade students of SMA 9 Makassar. The research used pre-experimental method. The population of this research was the first grade students of SMA 9 Makassar. The sample was 20 students . Based on the result of the data, there was a significant difference between pre-test and post-test of the students' improvement in reading comprehension. It indicated by the mean score of students' post-test which was higher than the mean score of the students' pre-test $(86.5>64)$. Based on the data analysis, it can be concluded that the implementation of 7 Smart Reading Strategy can improve the students' reading comprehension.
\end{abstract}

\section{Keywords}

7 Smart Reading Strategy, students' reading comprehension

\section{Introduction}

A language is one of primary source of communication which is used to share our ideas and thoughts with other people. Some people even think that language is what separates us from animals and make us human. Nowadays, English is considered as a universal language and its knowledge seems to be crucial. In learning a language consist of the language itself and the cultural background of the country.

English is a foreign language in Indonesia which is taught from elementary schools up to university as a compulsory subject. Events in some school in a big town like Makassar it is taught as a local content. The main goal of learning English is to produce and comprehend it in spoken and written. People think that a successful English learner is person who can speak English correctly and fluently.

There are four skills in English namely speaking, writing, listening and reading. Reading skill is in language should be mastered by the students in other to success in earning English. Reading is very important in our daily life which is used to expose new things, new information, new ways to solve problem and new ways to achieve one thing. Reading is also very important in the process of learning because it helps the students to think in English, build English vocabulary, can encourage the students to focus on the grammar and punctuation which make them comfortable in learning reading skill. Besides that reading is also an essential skill for the students at all level in other to find as much information and news from all over the world especially in globalization era.

There are some difficulties for the students in Junior High School in learning process such as (1) the students are lack of vocabulary which influence them while reading the text and they feel difficult in understanding the text, (2) the students are feel difficult to understand the meaning of the text given by the teacher. The teacher usually help the students to read the word by word or sentence by sentence, (3) the students do not have good motivation to read because the text is not interesting and they feel reading activity is boring and they become passive and lazy to read.

It is not so easy to improve the students' reading comprehension. It is based on the researcher observation while 
doing his interview with the teacher of SMK 9 Makassar. The result of teaching reading in the school is not satisfactory yet because of some factors such the students' lack of vocabulary, the text was difficult which beyond the students' knowledge and experience, the students' motivation in reading was low and it would influence their achievement. From this information that the researcher got from the interview from one of the teacher the researcher will use the implementation 7 Smart Strategy in teaching reading comprehension at SMKA 9 Makassar.

Based on the background above, the researcher formulates research question as follow: Does the implementation of 7 Smart strategies improve the students' reading comprehension of the first grade students of SMA 9 Makassar.

The result of the study is expected to be useful in theoretically and practically. Theoretically, the result of the research is expected to give valuable knowledge in teaching reading comprehension by using Smart 7 strategy at Junior High school of SMA 9 Makassar. Practically, the result of the study for the teacher is expected to give contribution dealing with the problem in teaching reading comprehension and for the students the result was intended to increase the students' reading comprehension and can raise their motivation in improving their achievement in learning reading comprehension.

This research is restricted on the implementation of 7 Smart Reading Strategy in improving the students' reading comprehension at SMA 9 Makassar. The researcher focused on literal reading comprehension by using narrative text.

Many researchers have reported in exposing some previous finding related to this research as follows:

Fitriyah (2014) in her research by using smart reading strategy gives significant effect toward the students' reading comprehension.

Rosdiana (2015) said the smart strategy was good in improving the students' reading comprehension when comparing to the use of convention method. In other words, the students who were learning by using smart reading strategy is better than the conventional method. While Lukman (2016) concluded in his research that the finding indicated that smart strategy was successful to enhance the students' motivation to be actively involved in the instructional process. The improvement on the students' participation was $75 \%$ in cycle 1 and $87 \%$ in cycle 2 . It means that the students' motivation in reading can be enhanced.

From the definition above the researcher want to conduct a research related to improve the students' reading comprehension of the students of SMA 9 Makassar.

Reading is one of the most important skills in learning English that is needed to understand the meaning provided in the text. In other words, reading is skill which is needed complicated process that becomes a bridge for the students in understanding the text. The students will get more information concerning some changing in different aspect such as knowledge and technology. According to Donald Hall (2017) said that reading is an activity desirable in it itself. It is understandable that the publishers and even written should promote this assumption. While Lukman (2016) said that reading is one of the language skills that play significant roles in teaching English as a foreign language.

Harmer (2007) stated that reading is useful for a language acquisition. Provided that the students more or less understand what they read, the more they read. Reading is also has a positive effect on students' vocabulary knowledge, on their spelling or on their writing. Reading consists of two related processes : word recognition and comprehension. Words recognition refers to the process of perceiving how written symbols correspond to one's spoken language. Meanwhile, comprehension is the process of making sense words, sentences and connected texts. While Richard (2002) said that reading includes discovering meaning in print and script, within a social context, through bottom-up and topdown processing and the use of strategies and skills.

Nunan (2003) said that reading is a fluent process of the readers' information from the text and their own background knowledge to build meaning. Or reading is an essential skill for the learner of English as a second language. While Mohan (2015) sated that reading is the communication between the reader and the writer.

From the definition above it can be concluded that reading is the learning process to identify the word and to understand the word in the text. Reading is an interactive process and communication between the reader and the writer in the text.

Neubaer (2018) stated that smart 7 strategies is a set of reading strategies for standardized testing. A seven strategy that is easy to follow the steps. This strategy is great for the students who have test anxiety or trouble focusing and apply to any form of short text with multiple choice responses. Kennedy (2016) stated that smart 7 strategy is a set of reading which consist of 7 steps, where students read and the box the title, number the paragraph or text features, read each paragraph then stop and think about. 
What you have read, write one to three keywords in the margin for each paragraph, read the question and underline one to three key words and the main idea of the text, read each answer and eliminate wrong choices, prove your answer then mark your answer.

According to Kennedy (2016), there are 7 steps of smart 7 reading strategy namely : (1) read and box the title. This will help the students to identify the texts, (2) number the paragraphs. This will help the students to separate the information into chucks rather than one large piece. (3) research the paragraph. Stop and think about what you have read. Write 1 to $3 \mathrm{key}$ words in the margin for each paragraph. This will prompt the students to memorize as he or she reads instead of at the end, (4) read each question: underline the key words. The student can then match the key words of the question to the key words from each paragraph, (5) read each answer and put (correct), (?), (X) beside each choice. Here the students label each possible answer to begin eliminating choices, (6) prove your answer. Go back to the passage and find the details to support your first choice or to eliminate a questions choices, (7) mark your answer. Fill in the bubble for your final answer.

\section{Method of the Research}

In this research, the researcher applied pre-experimental research. It includes pre-test, treatment and post-test. Pre-test was done at first to know the students' prior knowledge in reading comprehension text. Treatment is the implementation of 7 SMART Reading Strategy in teaching learning activities for four times. While post-test was done to know the students' reading comprehension after teaching by the use 7 smart reading strategy.

The design was presented as follows:

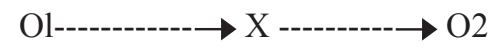

Where : $\mathrm{Ol}=$ Pre-test

$\mathrm{O} 2=$ Treatment

O3 = Post-test

Gay (2006)

There are variables of this research namely independent variable and dependent variable. The independent variable is the use of 7 Smart Reading Strategy and the dependent variable was the students' reading comprehension development.

The population of this research was the first grade students of SMA 9 Makassar. The total students was 120 which consist of 6 classes namely XMIA I, X MIA 2, X MIA 3, X MIA 4, X MIA 5 and X MIA 6.

In this research the researcher used purposive sampling technique. The sample was one class from the first year students of X MIA 3 which consisted of 20 students. The researcher chooses this class because the students had low skill in comprehending the reading text.

In collecting the data, the researcher used multiple choices question that consisted of 20 questions from a given reading text in pre-test and post-test. The pre-test was given to find the initial ability before presenting the 7 Smart Reading Strategy and the post-test was given to find out the result of the students' reading comprehension.

To collect the data, the researcher followed the procedures as follows:

1. Pre-test. The pre-test was given to the students about their reading comprehension before teaching by implanting the 7 smart reading strategy.

2. Treatment. The treatment was carried out for four meetings by implementing the 7 smart reading strategy in teaching reading comprehension. Each meeting took 90 minutes.

3. Post-test. After given treatment the researcher provided post-test to find out the students' result after given treatment.

\section{Finding and Discussion}

This chapter particularly presented the findings and the discussions. The finding presents the result of the students' score in both pre-test and post-test. While the discussion presents the result of the findings.

The result of the students' pre-test was very low. The researcher found out that there were 9 students $(45 \%)$ got fairly good category, 8 students (40\%) obtained fairly category, 5 students (16.66\%) obtained or classified into fair level, 3 
students (15\%) were classified into poor score and none of the students got excellent, very good and very poor category. From this result it could be concluded that the students were very low in understanding and answering the reading text. In this case, the result of pre-test showed that the ability of the students, how far the students could understand about the reading text and to identify all aspects in reading.

After giving treatment by implementing the 7 Smart reading strategy the researcher found out that the strategy was effective in improving the students reading comprehension by giving post-test. In the post-test the researcher found out that many of the students were able and easy to do the question in the text. They were great enthusiasm to do the test and it seemed of the expression on the students' faces when doing the test. Besides that the students did the test so fast and collected their worksheet before the time finish.

After the post-test the researcher found out that the result of the test was better than when comparing before and after using or implementing the 7 Smart reading strategy. After tabulating the post-test the researcher found that 1 student $(5 \%)$ was classified into excellent category, 8 students (40\%) were classified into very good category, 9 students $(45 \%)$ were classified into good category, 2 students $(10 \%)$ were classified into fairly good category, none of the students $(0 \%)$ were classified into fair category and also no student $(0 \%)$ was classified into very poor category. Finally the researcher concluded that the 7 Smart reading strategy could be used to improve the students' achievement in reading comprehension test.

After knowing and understanding the result of the students in pre-test and post-test of the reading comprehension by implementing the 7 smart reading strategy, the researcher then compared the result into the percentage criteria, frequency of the students, and scores of the students in pre-test and post-test . In the frequency and rate percentage of the students' achievement in pre-test could be classified into very poor category. While the score from frequency and rate percentage of the students' post-test of reading comprehension could be classified into very good category.

The result of the students' reading comprehension through 7 smart reading strategy have been improved. In pre-test $0 \%$ students were obtained excellent while in post-test $5 \%$ were achieved as excellent category. In pre-test $0 \%$ students were classified as very good while in post-test $40 \%$ students were classified into very good category. In pre-test $0 \%$ students were classified into good category while in post-test $45 \%$ students were classified into goo category. In pre-test $45 \%$ students were classified into fairly good category while in post-test $10 \%$ students were classified into fairly good category. In pre-test $40 \%$ students were classified into fair category while in post-test $0 \%$ students were classified into fair category. In pre-test $15 \%$ students were classified into poor category while in post-test $0 \%$ students were classified into poor category. In pre-test $0 \%$ students were classified into poor category while in post-test $0 \%$ students were classified into poor category.

From the finding above it showed that $25(100 \%)$ students' scores were increased and none of the students got lower scores. It mean that $100 \%$ of the students' scores were increased. By seeing the simulation of the students' score, the researcher concluded that the students reading comprehension was developed. There was a significant difference before and after giving the treatment by using 7 smart reading strategy at the first grade students of SMA 9 Makassar. On other words, the implementation of 7 smart reading strategy was effective in improving the students' reading comprehension.

The mean score of the students' pre-test was 64 while the mean score of the students' post-test was 85.6. It showed that the mean score of the post-test was higher than the mean score of pre-test. In other words, the teaching of reading comprehension by implementing the 7 smart reading strategy can improve the students' reading comprehension of the first grade students of SMA 9 Makassar

\section{Discussion}

Before the students were taught by smart reading strategy that is used in this research, the researcher had given the students pre-test in other to know the students' prior knowledge in reading comprehension. After that the researcher gave treatment by using 7 smart reading strategy for four times then the students were given post-test. The post-test was given to find out the students' development in reading comprehension.

In implementing the treatments, the researcher worked together with the English teacher. When the researcher took role as a teacher the English teacher stayed at the back. The English teacher observed the learning process, completing the observation sheet and recording the activities in the classroom. The treatment was conducted in four meeting. At last the researcher gave guidance to the students how to use 7 smart reading strategy and let the students to work independently although the discussion in groups was still provided. After the students did the procedures of 7 smart reading strategy 
then the students were asked to answer the questions given. The questions were given to measure the student s' reading comprehension.

During the treatment, the researcher found some difficulties faced by the students. The most difficulty faced by the students were the difficulties in understanding the reading text and lack of vocabulary mastery of the students. In this case the questions given by the researcher, the students were unable to answer the reading text. In minimizing the students' problem in answering the questions they were asked to use a dictionary and asked to memorize the words they did not know. On the last step, the researcher gave some reading text and asked them to answer the question given which were very successful.

At last meeting, the researcher gave post-test to the students. In the post-test the students only took 40 minutes to do the test. After checking the students' answer, the students' reading comprehension was improved.

From the discussion above, the researcher concluded that the first grade students of SMA 9 Makassar have a good comprehension result after the learning the reading using the 7 smart reading strategy. In other words, the value of t-test was greater than t-table (6.881>1.729), it means that there was a significance different between pre-test and posttest achievement after implementing 7 smart reading strategy. Finally the researcher suggested to the teacher to use the 7 smart reading strategy in teaching reading comprehension because this strategy as a media in teaching and learning reading was effective in improving the students' reading comprehension.

\section{Conclusion and Suggestions}

This chapter presents the conclusion and suggestions based on the findings and discussion of the data.

After doing the research the researcher got result and made some conclusion as follows:

This strategy was successful in improving the students' reading comprehension. The implementation of 7 smart reading strategy provided the students " opportunities to answer the questions, to dramatize and style of recitation materials given during the teaching and learning process of reading comprehension. It recommended that the teacher could use this strategy in their reading comprehension subject since the students are happy in doing their tasks and comprehend the text well.

The result of the data analysis showed that the mean score of the students post-test was higher than the pre-test (86.5 $>64)$. There was a significant difference between the result of pre-test and post-test which indicates that the using of 7 smart reading strategy in teaching reading helps the students to improve their reading comprehension.

After seeing above the positive of the research, the researcher suggests some suggestions as follows:

The researcher suggested for the English teacher to use the 7 smart reading strategy in teaching reading comprehension because it is effective to develop the students' reading comprehension and also to make the students more active in to learn in the classroom. In other to make the learning process effectively it is wise to apply appropriate learning strategy.

Finally the researcher suggested to other researcher to explore more about reading comprehension by using 7 smart reading strategy.

\section{Bibliography}

Buehi, Dough. 2001. Classroom Strategies for Interactive Learning. Newwart: International Reading Association.

Creswell, W John. 2008. Research Design International Education Research Planning, Conducting, And Evaluating Quantitative and Qualitative Research. Third Edition: University Of Nebraska Lincoln.

Donald Hall Pearson. 2007. Four Kinds of Reading: Classification and Devision.

Fitriyah, Masnunatul. 2014. The effectiveness of Using Smart Strategy in Reading Comprehension Of Second Grade Students at MTs Alhuda Kedungwaru in the Academic year 2013/2014. Thesis of University Kediri.

Gay, L. R. 2006. Educational Research: Competencies for Analysis and Applicant. New Jersey: Prentice Hall.

Harmer, Jeremy. 2007. How to Teach English. New York: Longman.

Nunan, David. 2003. Practical English Language Teaching. Singapore: McGraw-Hill Education.

Richard, Jack C \& Reanandya, Willy A. 2002. Methodology in Language Teaching. Cambridge University Press. Westwood, Peter. 2008. What Teachers Need to Know About Reading and Writing Difficulties : ACER Press. 